\title{
Erythroid Colony Forming Unit
}

National Cancer Institute

\section{Source}

National Cancer Institute. Erythroid Colony Forming Unit. NCI Thesaurus. Code C121533.

A unit of viable cell concentration defined as the minimum number of hematopoietic stem cells able to produce a detectable colony of erythroid lineage cells that are past the burst forming stage. 